\title{
Parasite identification, succession and infection pathways in perch fry (Perca fluviatilis): new insights through a combined morphological and genetic approach
}

\author{
JASMINCA BEHRMANN-GODEL* \\ Limnological Institute, University of Konstanz, 78464 Konstanz, Germany
}

(Received 5 March 2012; revised 20 September and 18 October 2012; accepted 18 October 2012; first published online 2 January 2013)

\begin{abstract}
SUMMARY
Identification of parasite species is particularly challenging in larval and juvenile hosts, and this hampers the understanding of parasite acquisition in early life. The work described here employs a new combination of methods to identify parasite species and study parasite succession in fry of perch (Perca fluviatilis) from Lake Constance, Germany. Classical morphological diagnostics are combined with sequence comparisons between parasite life-stages collected from various hosts within the same ecosystem. In perch fry at different stages of development, 13 different parasite species were found. Incomplete morphological identifications of cestodes of the order Proteocephalidea, and trematodes of the family Diplostomatidae were complemented with sequences of mitochondrial DNA (cytochrome oxidase 1) and/or nuclear (28 s rDNA) genes. Sequences were compared to published data and used to link the parasites in perch to stages from molluscs, arthropods and more easily identifiable developmental stages from other fishes collected in Lake Constance, which both aided parasite identification and clarified transmission pathways. There were distinct changes in parasite community composition and abundance associated with perch fry age and habitat shifts. Some parasites became more abundant in older fish, whereas the composition of parasite communities was more strongly affected by the ontogenetic shifts from the pelagic to the littoral zone.
\end{abstract}

Key words: parasite community, transmission, Diplostomatidae, Proteocephalidea, barcoding genes, 28s rDNA, CO1, ITS1-5.8s-ITS2 rDNA.

\section{INTRODUCTION}

Many marine and freshwater fish species produce vast numbers of eggs. Only a minority will be fertilized, hatch, develop into juveniles and reach maturity. High levels of larval and juvenile mortality are due mainly to predation but starvation, disease and parasitism also take a significant toll (Wootton, 1998). An increasing number of studies show that the early developmental stages of fish are targeted by several species of endo- and ectoparasites (Balbuena et al. 2000; King and Cone, 2009; Pracheil and Muzzall, 2009; Skovgaard et al. 2009a). Parasitic infections may be detrimental to fish fry (Grutter et al. 2009; Skovgaard et al. 2009b; Kelly et al. 2010; Nendick et al. 2011), but there still is a tremendous lack of knowledge about the relationship, especially in freshwater systems. The timing of first parasite encounter and subsequent parasite succession are almost unstudied. The study of parasite infections in fish fry presents challenges because the young age of the hosts means that any infections observed must be very recent. Thus the parasites are themselves in early stages of development (Kuchta et al. 2009), and may lack important morphological characteristics

* Corresponding author: Tel: ++497531884536 . Fax: ++ 497531 883533. E-mail: Jasminca.Behrmann@unikonstanz.de required for precise species determination. Classically, this problem has been addressed with life-cycle studies including also experimental infections. However, such studies are laborious and usually limited to small numbers of congeneric parasites. In contrast, difficulty in the identification of parasite species often scales up to higher levels, such as that among cestodes of the order Proteocephalidea, and trematodes of the family Diplostomatidae (Wootten 1974; Kennedy, 1978).

Molecular identification techniques based on sequences of nuclear genes such as ribosomal rRNA and the mitochondrial cytochrome oxidase gene can be helpful in otherwise tricky species diagnoses (Zehnder and Mariaux, 1999; Scholz et al. 2007; Sonnenberg et al. 2007; Locke et al. 2010a,b). An increasing number of sequences are becoming available for comparison in various databases. Unfortunately, not all are backed up by solid taxonomic work, without which reference sequences cannot be fully relied on for species identification purposes. Furthermore, accordance between a reliable reference and the investigated sequence must be very good to allow confident species determination. This study develops a method that combines classical morphological analysis with a genetic survey of various parasite life-cycle stages to solve this problem. Preliminary identification of 
species of parasites infecting perch fry was carried out using morphological characteristics, and was supported by sequencing of DNA of other, more easily identifiable developmental stages from the same ecosystem. This method was also applied to investigate transmission between hosts. The data are used in an ecological investigation of macroparasite infection of perch fry in Lake Constance.

The Eurasian perch (Perca fluviatilis L.) is a widely distributed fish species of the Palaearctic region. Perch harbour a variety of ecto-and endoparasites belonging to various orders (Balling and Pfeiffer, 1997a-d; Carney and Dick, 1999; MorozinskaGogol, 2008), but very little is known about parasites of the larval and early juvenile life stages. The author knows of only 1 study, by Kuchta et al. (2009), which compared infection rates of perch fry from 3 spatially distinct subpopulations, epipelagic, bathypelagic and littoral, in a deep, canyon-shaped reservoir in the Czech Republic. The authors found 6 species of endoparasites. Infection rates increased with fish age and the highest infection rates were found in the littoral population. In deep, natural lakes in Europe and North America, the life histories of perch and its sister species yellow perch (Perca flavescens) typically include early habitat shifts. Perch spawn in May/June in the littoral zones. Soon after hatching, larvae are found in the pelagic zone where they remain up until metamorphosis. Soon afterwards they return to the littoral and inhabit shallow water until autumn when they move into deeper water to overwinter (Coles, 1981; Wang and Eckmann, 1994; Imbrock et al. 1996; Miehls and Dettmers, 2011). Thus perch occupy different habitats and exploit different food sources early in their ontogeny, switching from planktonic to benthic prey (Wang and Appenzeller, 1998; Weber et al. 2011). These niche shifts alter the exposure and vulnerability of young perch to a number of parasite species (Johnson et al. 2004; McCairns and Fox, 2004; Zelmer and Arai, 2004; Bertrand et al. 2008; Pracheil and Muzzall, 2009). For fish larvae and early juveniles, the consumption of zooplankton is a major route of infection with helminths. Their occurrence in the zooplankton is often spatially and temporally synchronized with the presence of intermediate and definitive hosts in spring (Rosenthal, 1967; Marcogliese, 1995; Johnson et al. 2006; Lahnsteiner et al. 2009). Young perch respond to seasonal changes in abiotic parameters such as water temperature and day length, which can also strongly influence the occurrence and density of infective parasite stages, including those whose complex life cycles involve many intermediate hosts, for example most cestodes and the digenean trematodes (Marcogliese, 1995; Faltynkova et al. 2009). Another challenge for larval and early juvenile fish is the slow maturation of their immune system during ontogeny. However, both the innate and the adaptive immune functions of perch can play a major role in the defence against helminth infections (Secombes and Chappell, 1996).

In this contribution, macroparasites were surveyed in order to characterize the chronology of infection in perch during the first 3 months of life in Lake Constance. Specifically, the aims were to (1) identify parasites of perch fry, (2) study parasite succession in perch fry, (3) investigate the effects of increasing age and the ontogenetic habitat shift of host fish on the development of the parasite community and (4) clarify transmission pathways between hosts.

\section{MATERIALS AND METHODS}

\section{Sampling and age determination of perch fry}

Perch were sampled from the large pre-alpine Upper Lake Constance in south Germany. Many previous studies on the perch life cycle have been conducted in this system and have shown that perch here undergo typical ontogenetic habitat shifts (Wang and Eckmann, 1994; Eckmann and Imbrock, 1996; Imbrock et al. 1996; Wang and Appenzeller, 1998). Larval perch were sampled from the pelagic zone of the lake at night, using an $800 \mu \mathrm{m}$ mesh ichthyoplankton net towed close to the surface by boat approximately $500 \mathrm{~m}$ offshore. These pelagic perch samples were from 2 different years. The 2 youngest samples were from 8 and 24 June 2010. Routine weekly samplings taken during and after the spawning season of this year, recorded the first yolk sac larvae in the pelagic zone on 1 June. Since perch use up their yolk sac within 1 week, the hatching date of the 2010 cohort was estimated to be 23 May. Hence, the ages of the first two pelagic samples were estimated at 2 and 4 weeks post-hatch (p.h.). The third pelagic and all littoral perch samples were from 2009 (pelagic sample from 1 and 7 July, littoral samples from 8 and 16 July and 14 and 16 August). Using 3 fish from each 2009 sample $(n=18)$, age was determined by counting daily increments on the lapilli (Campana, 1992). From these counts, a hatching date of 20 May was estimated for the 2009 cohort. Thus, the ages of the third pelagic and both littoral samples were estimated to be 7,8 and 12 weeks p.h. respectively. The two littoral perch samples were netted with beach seines of 2 and $4 \mathrm{~mm}$ mesh sizes hauled from $1 \mathrm{~m}$ depth to the shore at night. Live perch were transported in bottles of aerated lake water and killed with an overdose of MS 222. Fish that died during sampling were stored in $0 \cdot 64 \% \mathrm{NaCl}$ solution in small bags kept on ice, and examined within $24 \mathrm{~h}$.

\section{Parasite assessment and morphological identification}

Perch fry were squeezed between glass plates for microscopical analysis and every organ and tissue was examined for the presence of macroparasites. Additionally, the $\mathrm{NaCl}$ solutions in which dead fish had been stored were screened for escaped parasites. 
Parasites were identified based on typical morphological features identified in previous studies (Bykhovskaya-Pavlovskaya et al. 1964; Wootten, 1974; Schäperclaus, 1979; Scholz et al. 1998). All cestodes from the suborder Proteocephalidae and some of the Triaenophoridae were observed to be in very early developmental stages, and could thus be identified only to family level. For species determination, cestode subsets were removed from perch (2-4 weeks p.h.) of the 2010 cohort and from additional perch fry of 1 sampling event in 2011 and stored in 95\% ethanol for genetic analysis. To obtain comparative sequences, cestodes from both suborders were also sampled from various adult fish hosts in Lake Constance. Fish species sampled were adult perch $(n=4)$, whitefish Coregonus lavaretus $(n=2)$, arctic char Salvelinus alpinus $(n=1)$, northern pike Esox lucius $(n=1)$ and burbot Lota lota $(n=1)$. Fish were dissected and late developmental stage and adult cestodes were identified to the species level based on morphological characteristics as described above. Samples were stored in 95\% ethanol for genetic analysis.

Pelagic copepods (Cyclops spp.) were collected in June 2011 and from April to September 2012. Sampling for copepods took place in approximately the same location as perch fry had been caught, using an ichthyoplankton net $1.10 \mathrm{~m}$ in diameter with $200 \mu \mathrm{m}$ mesh. The net was towed approximately $0.5 \mathrm{~m}$ below the water surface behind a boat. Plankton samples were transported to the laboratory, sieved though $500 \mu \mathrm{m}$ mesh, collected in beakers with filtered lake water and stored at $4{ }^{\circ} \mathrm{C}$ until analysis. A small portion of the collected sample was placed in a glass Petri dish, anaesthetized with carbonated water and examined under a dissection binocular microscope. For further investigation cyclopoid copepods (copepodids C5 and adults) were dissected using Dumont tweezers and preparation needles and analysed for procercoid infection. All procercoids found were stored in 95\% ethanol. Then 19 procercoids (9 from 2011 and 10 from 2012) were selected at random for genetic analysis.

Eye flukes (metacercariae of diplostomatid trematodes) from perch fry were determined morphologically to family level only. For species determination via genetic comparison, metacercariae were sampled from the eye lenses and the vitreous body of several adult fish hosts in Lake Constance: perch $(n=9)$, ruffe Gymnocephalus cernuus $(n=1)$, whitefish $(n=2)$ and roach Rutilus rutilus $(n=1)$. To investigate the emergence of eye fluke cercariae in Lake Constance, lymnaeid snails Radix auricularia and R. labiata were sampled at 3 littoral locations between May and October 2010. Snails were taken to the laboratory and placed individually in $150 \mathrm{ml}$ plastic bowls for a maximum of 7 weeks. The temperature was $20^{\circ} \mathrm{C}$ and bowls were illuminated artificially with light: dark cycles corresponding to natural conditions. The snails were fed with commercial fish food $\left(\right.$ Tetramin $^{\circledR}$ ) and frozen chironomids and the water was exchanged every 2-3 days. Before water exchange, bowls were screened for shed cercariae. Cercariae of infected snails were observed under a microscope after vital staining with Neutral Red. Diplostomatid cercariae were morphologically determined to the family and where possible to the species level with the help of available literature (Niewiadomska and Kieseliene, 1994; Niewiadomska and Laskowski, 2002; Faltynkova, 2005). Cercariae were collected and stored in 95\% ethanol for later genetic analysis. From every infected snail, 2 cercariae were genetically analysed.

\section{Direct sequencing}

Parasite DNA was extracted from whole individuals, or from small pieces in the case of adult cestodes, using the Chelex ${ }^{\mathrm{TM}}$ extraction technique (Criscione and Blouin, 2004). The primer combinations LSU D1-D2 fw1 and LSU D1-D2 rev2 were used to amplify the D1-D2 fragment of the LSU rDNA gene region according to the protocol of Sonnenberg et al. (2007). For trematodes, part of the mitochondrial cytochrome oxidase subunit 1 (CO1) and the complete internal transcribed spacer 1 and 2 (ITS1$5 \cdot 8 \mathrm{~S}-\mathrm{ITS} 2)$ of the rDNA gene were amplified with the use of established primers and protocols: PlatdiploCOX1dF/R (Moszczynska et al. 2009) and D1/ 2 (Galazzo et al. 2002). PCR products were purified using Exo/FastAP (Fermentas), prepared for sequencing using the BigDye termination reaction chemistry (Applied Biosystems) and sequenced in both directions in an ABI 3130 capillary DNA sequencer (Applied Biosystems). All unique traces were compared to previously published sequences from GenBank with a BLAST search in order to find identical sequences. The LSU D1-D2, CO1 and ITS1-5.8S-ITS2 sequences from parasites found in this study were aligned with the help of BioEdit (Hall, 1999). Neighbour-joining (NJ) trees (Saitou and Nei, 1987) were constructed from a Kimura-2parameter distance matrix (Kimura, 1980) using MEGA software (Tamura et al. 2011).

Representative unique sequences of genes newly sequenced here were submitted to the GenBank database. These include 5 LSU rDNA gene region sequences from cestodes (GenBank ID: JQ639165-JQ639169), and 35 CO1 sequences (GenBank ID: JQ639170-JQ639204) and 5 ITS1$5,8 \mathrm{~S}-\mathrm{ITS} 2$ sequences from trematodes (GenBank ID: JQ665456 - JQ665460).

\section{Statistical analysis of the parasite community development}

To investigate the development of the parasite community of perch fry without interference or variability due to inter-annual variation, analyses 
Table 1. Parasite species, prevalence and mean intensity of infection found in perch of Lake Constance sampled at different age

(First 3 columns (2, 4 and 7 weeks p.h. (wph), grey box) represent the pelagic, the other 2 (8 and 12 weeks p.h.) the littoral samples. Proteocephalus spp. includes P. percae and P. longicollis). Added is information on the invertebrate hosts $(1 . \mathrm{IH}=$ first, $2 . \mathrm{IH}=$ second intermediate host $)$, the species names are given in parentheses if known for Lake Constance from own observations.)

\begin{tabular}{|c|c|c|c|c|c|c|}
\hline $\begin{array}{l}\text { Age wph ( } n \text { fish) } \\
\text { Year of sampling }\end{array}$ & $\begin{array}{l}2(51) \\
2010\end{array}$ & $\begin{array}{l}4(85) \\
2010\end{array}$ & $\begin{array}{l}7(52) \\
2009\end{array}$ & $\begin{array}{l}8(60) \\
2009\end{array}$ & $\begin{array}{l}12(60) \\
2009\end{array}$ & \\
\hline Parasite species & \multicolumn{5}{|c|}{ Prevalence (mean intensities) } & Invertebrate host \\
\hline $\begin{array}{l}\text { Cestoda } \\
\text { Triaenophorus nodulosus* } \\
\text { T. nodulosus** } \\
\text { Proteocephalus } \text { spp. } \\
\text { Eubothrium crassum }\end{array}$ & $\begin{array}{l}0(0) \\
0(0) \\
0(0) \\
0(0)\end{array}$ & $\begin{array}{c}0(0) \\
0(0) \\
12(1 \cdot 1) \\
70(3 \cdot 0)\end{array}$ & $\begin{array}{l}52(1 \cdot 5) \\
19(1 \cdot 4) \\
71(4 \cdot 8) \\
63(3 \cdot 5)\end{array}$ & $\begin{array}{r}40(1 \cdot 2) \\
2(1 \cdot 0) \\
42(3 \cdot 3) \\
88(6 \cdot 8)\end{array}$ & $\begin{array}{r}50(1 \cdot 5) \\
3(1 \cdot 0) \\
13(1 \cdot 3) \\
40(3 \cdot 8)\end{array}$ & $\begin{array}{l}\text { 1.IH: Copepods (Cyclops spp.) } \\
\text { 1.IH: Copepods (Cyclops spp.) } \\
\text { 1.IH: Copepods }\end{array}$ \\
\hline $\begin{array}{l}\text { Trematoda } \\
\text { Bunodera luciopercae }\end{array}$ & $0(0)$ & $6(1 \cdot 2)$ & $63(2 \cdot 7)$ & $87(4 \cdot 9)$ & $93(13 \cdot 2)$ & $\begin{array}{l}\text { 1.IH: Bivalves; 2.IH: Copepods, } \\
\text { cladocerans, ostracods, , amphipods, } \\
\text { ephemeroptera }\end{array}$ \\
\hline Diplostomum baeri & $0(0)$ & $0(0)$ & $0(0)$ & $13(1 \cdot 3)$ & $67(7 \cdot 2)$ & 1.IH: Snails \\
\hline Thylodelphys sp.2 & $0(0)$ & $0(0)$ & $0(0)$ & $52(2 \cdot 1)$ & $100(64)$ & 1.IH: Snails (Radix auricularia, $R$. labiata) \\
\hline $\begin{array}{l}\text { Ichthyocotylurus } \\
\text { variegatus }\end{array}$ & $0(0)$ & $0(0)$ & $0(0)$ & $0(0)$ & $15(4 \cdot 7)$ & 1.IH: Snails (Valvata piscinalis) \\
\hline Cotylurus pileatus & $0(0)$ & $0(0)$ & $0(0)$ & $8(1 \cdot 4)$ & $35(7 \cdot 2)$ & 1.IH: Snails \\
\hline Hysteromorpha triloba & $0(0)$ & $0(0)$ & $0(0)$ & $25(4 \cdot 0)$ & $22(1 \cdot 8)$ & 1.IH: Snails \\
\hline Bucephalus polymorphus & $0(0)$ & $0(0)$ & $0(0)$ & $5(1 \cdot 6)$ & $0(0)$ & 1.IH: Bivalves \\
\hline $\begin{array}{l}\text { Nematoda } \\
\text { Raphidascaris acus }\end{array}$ & $0(0)$ & $0(0)$ & $0(0)$ & $2(1 \cdot 0)$ & $0(0)$ & - \\
\hline $\begin{array}{l}\text { Maxillopoda } \\
\text { Ergasilus sieboldi } \\
\text { Argulus foliaceus }\end{array}$ & $\begin{array}{l}0(0) \\
0(0)\end{array}$ & $\begin{array}{l}0(0) \\
0(0)\end{array}$ & $\begin{array}{l}0(0) \\
0(0)\end{array}$ & $\begin{array}{l}0(0) \\
5(2 \cdot 0)\end{array}$ & $\begin{array}{l}1(1 \cdot 0) \\
5(1 \cdot 6)\end{array}$ & - \\
\hline
\end{tabular}

* Plerocercoids; ** Procercoids.

were restricted to data for 1 year class, including 7,8 and 12 -week-old fish of the 2009 cohort. In this analysis, the abundance of each parasite species was determined for every fish. A Bray-Curtis dissimilarity matrix was then calculated and the relationship between fish age and parasite community structure was visualized with 2-dimensional nonmetric multidimensional scaling (nMDS; Kruskal, 1964) using the software PRIMER-E v6 (Clarke, 1993). The nMDS yields a plot in which the parasite community of each individual fish is represented as a dot. The closer together the dots appear on the plot, the more similar the parasite communities of individual fish are to one another. In labelling fish by age (weeks 7, 8 and 12), age-related clustering can be visualized. The difference in parasite communities between the 3 age groups was tested for significance with an analysis of similarity (ANOSIM) implemented in the software PRIMER-E.

\section{RESULTS}

\section{Parasite species identification based on morphological characteristics}

The perch fry sampled in this study were infected with 13 different parasite taxa (Table 1). Nine species could be identified unambiguously to species level based on morphological characters: Bunodera luciopercae, Triaenophorus nodulosus (hook carrying plerocercoids in perch liver), Cotylurus pileatus, Ichthyocotylurus variagatus, Hysteromorpha triloba, Bucephalus polymorphus, Raphidascaris acus, Argulus foliaceus and Ergasilus sieboldi. The cestode Eubothrium, could be identified to family level since the typical scolex grooves had already developed.

From adult fish hosts the following species were identified: Proteocephalus percae from perch, Proteocephalus longicollis from white fish, Eubothrium salvelini from arctic char, Eubothrium crassum from burbot and Triaenophorus nodulosus from pike.

\section{Parasite species identification via direct sequencing}

Based on sequence analysis 5 different cestode and 5 different trematode (eye fluke) species were identified from various hosts (Table 2, Fig. 1).

Sequence analysis of D1-D2 fragments from the LSU rDNA gene region of cestodes from adult fish hosts revealed several mutational steps between the different parasite sequences (Supplementary Fig. S1, online version only), which resulted in 
Table 2. Fish parasites analysed via direct sequencing form various host species of Lake Constance (LC)

(Added also is information on the typical invertebrate host species from the literature.)

\begin{tabular}{|c|c|c|c|c|c|c|}
\hline Parasite species & Host species LC & $\begin{array}{l}\text { No. parasites } \\
\text { found }\end{array}$ & Location in host LC & Gene(s) sequenced & $\begin{array}{l}\text { First intermediate } \\
\text { host described }\end{array}$ & References \\
\hline \multicolumn{7}{|l|}{ Cestodes } \\
\hline Proteocephalus percae & $\begin{array}{l}\text { Perch adult } \\
\text { Perch fry } \\
\text { Burbot }\end{array}$ & $\begin{array}{r}10 \\
1 \\
1\end{array}$ & $\begin{array}{l}\text { Gut } \\
\text { Gut } \\
\text { Gut }\end{array}$ & LSU rDNA & $\begin{array}{l}\text { Cyclops spp. } \\
\text { Macrocyclops spp. } \\
\text { Megacyclops spp. } \\
\text { Eudiaptomus spp. }\end{array}$ & Scholz, 1999 \\
\hline Proteocephalus longicollis & $\begin{array}{l}\text { Perch fry } \\
\text { Whitefish } \\
\text { Cyclops spp. }\end{array}$ & $\begin{array}{r}13 \\
8 \\
15\end{array}$ & $\begin{array}{l}\text { Gut } \\
\text { Gut } \\
\text { Haemocoel }\end{array}$ & LSU rDNA & $\begin{array}{l}\text { Cyclops spp. } \\
\text { Megacyclops spp. } \\
\text { Mesocyclops spp. } \\
\text { Eudiaptomus spp. }\end{array}$ & Scholz, 1999 \\
\hline Eubothrium crassum & $\begin{array}{l}\text { Perch fry } \\
\text { Burbot } \\
\text { Cyclops spp. }\end{array}$ & $\begin{array}{r}21 \\
1 \\
1\end{array}$ & $\begin{array}{l}\text { Gut } \\
\text { Gut } \\
\text { Haemocoel }\end{array}$ & LSU rDNA & Cyclops spp. & Hanzelová et al. 2002; Kennedy, 1978 \\
\hline Eubothrium salvelini & Arctic charr & 5 & Gut & LSU rDNA & Cyclops spp. & $\begin{array}{l}\text { Hanzelová et al. 2002; Kennedy, 1978; Poulin } \\
\text { et al. } 1992\end{array}$ \\
\hline Triaenophorus nodulosus & $\begin{array}{l}\text { Perch fry } \\
\text { Pike } \\
\text { Cyclops spp. }\end{array}$ & $\begin{array}{l}2 \\
1 \\
3\end{array}$ & $\begin{array}{l}\text { Liver/gut } \\
\text { Gut } \\
\text { Haemocoel }\end{array}$ & LSU rDNA & $\begin{array}{l}\text { Cyclops spp. } \\
\text { Eudiaptomus spp. }\end{array}$ & Kuperman, 1981; Pronin, 1990 \\
\hline Trematodes & & & & & & \\
\hline Diplostomum baeri & $\begin{array}{l}\text { Perch adult } \\
\text { Ruffe }^{\#}\end{array}$ & $\begin{array}{r}39 \\
2\end{array}$ & $\begin{array}{l}\text { Eye vitreous } \\
\text { Eye vitreous }\end{array}$ & CO1/ITS1 + 2 & Radix auricularia & Niewiadomska and Kiseliene, 1994 \\
\hline $\begin{array}{l}\text { Diplostomum } \\
\text { pseudospathaceum }\end{array}$ & $\begin{array}{l}\text { Ruffe } \# \\
\text { Radix labiata }\end{array}$ & $\begin{array}{l}1 \\
9\end{array}$ & $\begin{array}{l}\text { Eye lens } \\
\text { Cercaria release }\end{array}$ & $\mathrm{CO} 1 / \mathrm{TS} 1+2$ & $\begin{array}{l}\text { Radix auricularia } \\
\text { Radix labiata } \\
\text { Lymnaea stagnalis } \\
\text { Galba palustris }\end{array}$ & $\begin{array}{l}\text { Niewiadomska and Kiseliene, 1994; } \\
\text { Niewiadomska and Laskoswki 2002; Faltýnková, } \\
2005\end{array}$ \\
\hline Diplostomum spathaceum & $\begin{array}{l}\text { Roach* } \\
\text { Radix auricularia }\end{array}$ & $\begin{array}{l}2 \\
1\end{array}$ & $\begin{array}{l}\text { Eye lens } \\
\text { Cercaria release }\end{array}$ & CO1/ITS1 + 2 & $\begin{array}{l}\text { Radix auricularia } \\
\text { Radix labiata } \\
\text { Lymnea stagnalis }\end{array}$ & Niewiadomska and Kiseliene, 1994; Vojtec, 1989 \\
\hline $\begin{array}{l}\text { Diplostomum } \\
\text { paracaudum }\end{array}$ & $\begin{array}{l}\text { Ruffe }^{\#} \\
\text { Whitefish } \\
\text { Radix auricularia }\end{array}$ & $\begin{array}{l}1 \\
1 \\
1\end{array}$ & $\begin{array}{l}\text { Eye lens } \\
\text { Eye lens } \\
\text { Cercaria release }\end{array}$ & CO1/ITS1 + 2 & $\begin{array}{l}\text { Radix auricularia } \\
\text { Galba palustris } \\
\text { Lymnea corvus }\end{array}$ & $\begin{array}{l}\text { Niewiadomska and Szymanski, 1991; } \\
\text { Faltýnková, } 2005\end{array}$ \\
\hline Tylodelphys sp 2. & $\begin{array}{l}\text { Perch adult } \\
\text { Whitefish } \# \\
\text { Radix auricularia } \\
\text { Radix labiata }\end{array}$ & $\begin{array}{l}7 \\
5 \\
5 \\
3\end{array}$ & $\begin{array}{l}\text { Eye vitreous } \\
\text { Eye vitreous } \\
\text { Cercaria release } \\
\text { Cercaria release }\end{array}$ & CO1/ITS1 + 2 & $\begin{array}{l}\text { Radix auricularia } \\
\text { Radix labiata }\end{array}$ & Tylodelphys spp.: Vojtec, 1989; Faltýnková, 2005 \\
\hline
\end{tabular}

* Only CO1 gene fragment sequenced.

\# Only ITS1 + 2 region sequenced. 

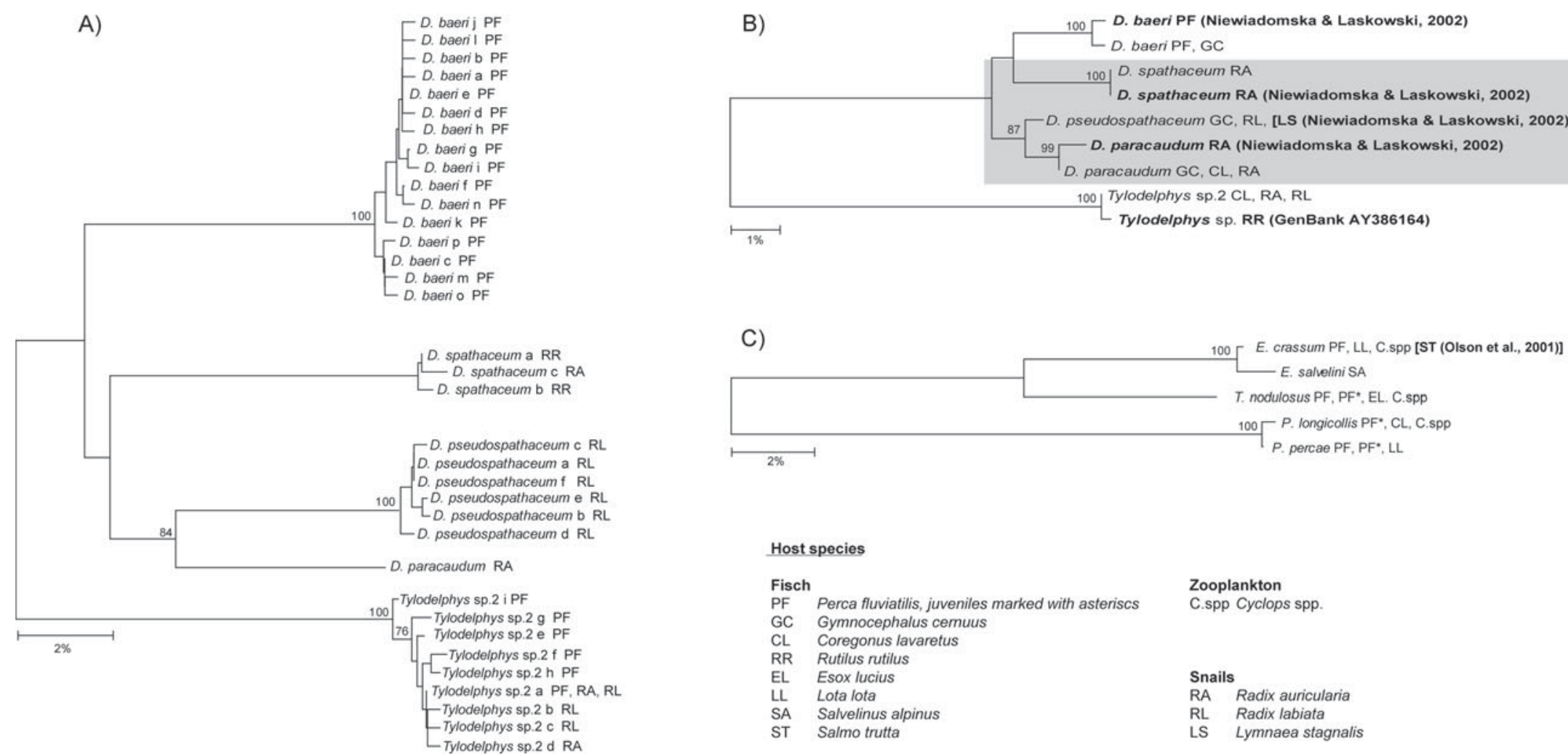

\section{Host species}

$\begin{array}{ll}\text { Fisch } & \text { Zooplankton } \\ \text { PF Perca fluviatilis, juveniles marked with asteriscs } & \text { C.spp Cyclops spp. } \\ \text { GC Gymnocephalus cemuus } & \\ \text { CL Coregonus lavaretus } & \\ \text { RR Rutilus rutilus } & \\ \text { EL Esox lucius } & \text { Snails } \\ \text { LL Lota lota } & \text { RA Radix auricularia } \\ \text { SA Salvelinus alpinus } & \text { RL Radix labiata } \\ \text { ST Salmo trutta } & \text { LS Lymnaea stagnalis }\end{array}$

Fig. 1. NJ trees from Kimura-2 parameter distances of trematodes and cestodes (1000 bootstraps, only bootstrap support $>70 \%$ is given on the nodes). (A) CO1 sequences ( 388 bp fragment) of trematodes. (B) ITS1 sequences ( $577 \mathrm{bp}$ fragment) of trematodes, grey box highlights species found in the eye lenses of fish hosts. Sequences from GenBank are marked in bold. (C) D1-D2 fragment of the LSU rDNA gene region (870 bp fragment) of cestodes. 
clear clustering in the cestode $\mathrm{NJ}$ phenogram (Fig. 1C). However, no intraspecific variation was detected.

The comparison with published sequences from GenBank revealed only 1 accordance, a $100 \%$ match with a sequence published for Eubothrium crassum, GenBank Accession number AF286947, described by Olson et al. (2001) (Fig. 1). For all other cestode species, no good accordance could be found with sequences from specimens sampled in this study. Thus the sequences of both Proteocephalus species sampled in this study differed from those published for both $P$. longicollis (syn. $P$. exiguus) GenBank Accession number AJ388626.1 and $P$. percae GenBank Accession number AJ288594.1 described by Zehnder and Mariaux (1999). In both instances there were numerous substitutions ( 3 and 21 respectively) and sequence gaps ( 8 and 3 respectively). No sequences were available in GenBank for Eubothrium salvelini or Triaenophorus nodulosus.

Proteocephalus percae as identified from adult perch was also present in 1 juvenile perch from the pelagic zone and in burbot. Proteocephalus longicollis, identified from whitefish, also occurred in perch fry and in 15 copepods from the pelagic zone. Eubothrium crassum, identified in burbot, was also found in perch fry and 1 copepod. Eubothrium salvelini was identified from Arctic char and found only in this species. Triaenophorus nodulosus was identified from pike and also occurred in juvenile perch and 3 copepods from the pelagic zone (Table 2).

Sequencing a fragment of the CO1 gene and the rDNA ITS $1+2$ region from trematodes obtained from various host species (Table 2) allowed further species identification based on numerous mutational differences between parasites (Supplementary Figs $\mathrm{S} 2$ and S3 respectively, online version only). While no intraspecific variation was found based on the alignment of the rDNA ITS $1+2$ region, high intraspecific variation occurred when considering the alignment of the mitochondrial CO1 subunit (Fig. 1A, and Supplementary Fig. S2, online version only). A BLAST search based solely on the ITS 1 gene region of the Diplostomum specimen found in this study allowed specimens to be assigned to 4 species (Diplostomum baeri GenBank Accession number AF419274.1, Diplostomum pseudospathaceum GenBank Accession number AF419273.1, Diplostomum spathaceum GenBank Accession number AF419276.1 and Diplostomum paracaudum GenBank Accession number AF419272.1) described by Niewiadomska and Laskowski (2002). Accordance between the sequences found here and the sequences of Niewiadomska and Laskowski (2002) was between 100\% (Diplostomum pseudospathaceum) and 99\% (remaining 4 species) (Fig. 1B). It must be noted, that Diplostomum spathaceum and Diplostomum parviventosum (GenBank Accession number AF419277-1) cannot be separated according to their
ITS1 sequences (Niewiadomska and Laskowski, 2002). However, based on typical morphological characteristics of the cercariae (Niewiadomska and Kiseliene, 1994), D. spathaceum and D. parviventosum can be distinguished. D. spathaceum is in general larger than D. parviventosum (total length $717-887 \mu \mathrm{m}$ for D. spathaceum and $529-645 \mu \mathrm{m}$ for $D$. parviventosum respectively) and its acetabulum exceeds the width of the anterior organ whereas it is much smaller in D. parviventosum. The cercariae, shed by $R$. auricularia sampled in this study were $750 \mu \mathrm{m}$ long and their acetabulum exceeded the anterior organ, thus they could be identified as $D$. spathaceum (Supplementary Fig. S4, online version only). All Tylodelphys specimens found could be assigned to 1 species. In contrast to the various ITS1 Diplostomum sequences available in GenBank, only a single Tylodelphys sequence was found Tylodelphys sp. GenBank Accession number AY386164. Our sequence differed from that published in GenBank by 3 base-pair substitutions, and thus we referred to it hereafter as Tylodelphys sp. 2 (Fig. 1B). In perch, only Diplostomum baeri and Tylodelphys sp. 2 were found (Tables 1 and 2). No mitochondrial CO1 sequences were available in GenBank for European trematodes and our sequences differed substantially from the North American Diplostomum species described by Locke et al. $(2010 a, b)$.

\section{Chronology of infection and parasite community development}

The Lake Constance perch fry sampled in this study exhibited a very specific chronology of parasite infection (Table 1). The first fish larvae caught in the pelagic zone in 2010 were 2 weeks old and appeared to be free of parasites. At 4 weeks of age, pelagic juvenile fish from the same cohort were infected with 3 parasite species: Proteocephalus ( $P$. percae and P. longicollis), Eubothrium crassum and Bunodera luciopercae. The 7-week-old juveniles caught in 2009 in the pelagic zone were infected with the same parasite species as the 4-week-old fish in 2010 and, additionally, with Triaenophorus nodulosus. Perch caught in the littoral zone at 8 and 12 weeks of age (2009 cohort) were further infected with several species of digenean trematodes (Table 1). The eye flukes Tylodelphys sp. 2 and Diplostomum baeri, both found in the vitreous body (Table 2), reached high levels of prevalence, while 3 other species (Cotylurus pileatus, Ichthyocotylurus variegatus and Hysteromorpha triloba) occurred either at lower densities or were found only sporadically (Bucephalus polymorphus). In addition, 1 nematode, Raphidascaris acus, and 2 maxillopods, Argulus foliaceus and Ergasilus sieboldi, were found at low densities.

Parasite communities from fish of similar age clustered together in the nMDS plot, with younger fish occupying the left side of the graph and older 


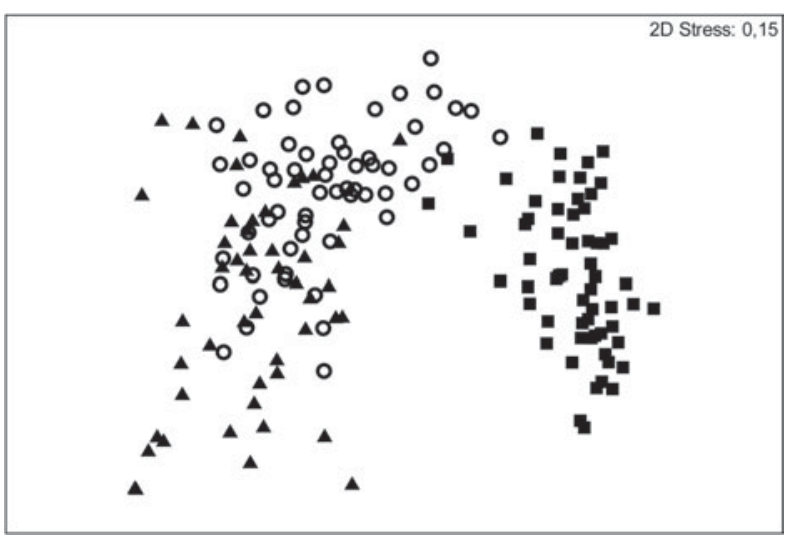

Fig. 2. Two-dimensional nonmetric multidimensional scaling (nMDS) plot calculated using Bray-Curtis ordination of parasite abundance data of perch fry sampled in Lake Constance in 2009. Triangles denote perch, sampled at week 7 , circles at week 8 and squares at week 12 post-hatch. Perch sampled at week 7 were caught in the pelagic, perch sampled at weeks 8 and 12 in the littoral zone of the lake.

perch appearing towards the right (Fig. 2). The stress value for the 2-dimensional nMDS analysis was $0 \cdot 15$ which indicated a reasonably good resolution for reliable interpretation of the data. The differences observed between the parasite communities of fish of the 3 age groups was significant based on ANOSIM (Global R=0.69, $P=0 \cdot 001$ ). Parasite communities between fish caught at week 7 in the pelagial and week 8 in the littoral had more overlap (Fig. 2) and a quite low $\mathrm{R}$ value in the ANOSIM $(\mathrm{R}=0 \cdot 23, P=0 \cdot 001)$, whereas the parasite communities of the 7 - and 8 -week-old fish groups were very different from those from fish caught at week 12 in the littoral (ANOSIM: week 7 vs 12: $\mathrm{R}=0.90, P=0.001$; week 8 vs 12: $\mathrm{R}=0 \cdot 86, P=0 \cdot 001)$.

\section{Emergence of infective stages from intermediate hosts and transmission to perch fry}

In total, 4207 cyclopoid copepods (Cyclops spp.) and 2003 snails (Radix auricularia and R. labiata) were analysed for infection with fish pathogenic species. The parasite prevalence varied substantially between sampling months (Table 3 ). In the pelagic Cyclops spp., cestode prevalence was very low from March to May (around 1\%) but increased thereafter to $15 \%$ in September. In the littoral zone, no cercariae were observed hatching from snails before July, but from July onwards, prevalence varied between 1 and 5\% until sampling ended in October. Genetic survey of parasite life-cycle stages indicated transmission of Proteocephalus longicollis, Eubothrium crassum and Triaenophorus nodulosus to perch fry via consumption of infected pelagic copepods, as all 3 species have been detected in both perch fry and Cyclops spp. (Table 2). Proteocephalus percae could not be found in 
pelagic Cyclops spp. but was detected in littoral Cyclops spp. in a more recent survey in Lake Constance (sampled 4 July 2012, data not shown).

Of all the different trematode cercariae found in the littoral snails, transmission to perch was indicated only for Tylodelphys sp.2 from Radix auricularia and R. labiata (Table 2). Tylodelphys sp.2 was also found infecting whitefish. Unfortunately, the snail host for Diplostomum baeri has not been identified thus far but other transmission pathways between snail and fish intermediate hosts were detected for the first time in Lake Constance (Table 2). For example, Diplostomum pseudospathaceum cercariae from Radix labiata were found infecting ruffe, Diplostomum spathaceum cercariae from Radix auricularia were found infecting roach and Diplostomum paracaudum cercariae from $R$. auricularia were found infecting ruffe and whitefish.

\section{DISCUSSION}

\section{Parasite succession and development of the parasite community}

Perch fry in Lake Constance first encounter macroparasites in the pelagic zone between 2 and 7 weeks p.h., when ingestion of zooplankton intermediate hosts leads to successive infection with helminths (cestodes and one trematode). Further evidence for this is the detection of infective parasite stages in pelagic copepods. After perch juveniles begin to return to the littoral zone at approximately 8 weeks $\mathrm{p}$. h., they are exposed to direct infection by trematodes hatching from various littoral snail intermediate hosts, and to sporadic infection with nematodes and maxillopods.

The observed changes in parasite infracommunites seemed to be caused by different mechanisms. The first shift, between week 7 and week 8 is mainly influenced by the addition of new species. This nicely reflects the move from a pelagic to a littoral habitat. Week 7 fish are infected exclusively with parasites from pelagic intermediate hosts, while by week 8 , host fish are additionally infected with trematodes stemming from littoral intermediate hosts. In contrast, the shift in parasite infracommunities between week 8 and week 12 is mainly characterized by intensification of existing infections, mainly of the littoral trematodes. Thus the parasite community of perch fry is influenced by both increasing age of perch and by ontogenetic habitat shift.

During the first days of life, perch larvae migrate from the littoral to the pelagic zone of the lake. In this study, the first larvae caught in the pelagic zone at the beginning of June were still in the yolk-sac stage. No larvae from this first sample were infected with macroparasites, indicating that either parasites were not encountered prior to the first habitat shift, or if that rapid mortality following direct and indirect infections meant that parasitized larvae died before reaching the pelagial. The data also showed that the first encounter with macroparasites in the pelagial happens via ingestion of infected prey. Interestingly, prevalence of procercoid infection in pelagic copepods began to increase in June, which matches well with the arrival of perch fry in the pelagial.

First infections with trematodes from snail intermediate hosts occurred after the juvenile perch had migrated back to the littoral zone. This is not surprising, because the snail intermediate hosts do not occur in the pelagial, and cercariae (infective freeliving stages of trematodes that hatch from snails) are relatively short-lived (max. 52 and $73 \mathrm{~h}$ for Diplostomum spp. and Tylodelphys sp.2 respectively, own unpublished observations). Additionally, due to their small size, cercariae are not very mobile. Despite the possibility of passive transport with offshore water currents we do not expect many cercariae in the pelagial and thus infection of perch before they migrate back to the littoral zone is highly unlikely. Interestingly, the timing of first cercariae release from littoral snails matches very precisely with that of the return migration of perch to the littoral zone in midJuly.

Almost all parasite species that were found in larval and juvenile perch are typical of adult perch from various regions (Andersen, 1978; Andrews, 1979; Valtonen et al. 2003; Morozinska-Gogol, 2008) and some have also been previously observed in adult perch from Lake Constance (Balling and Pfeiffer, $1997 a-d)$. However, the genetic analysis revealed 2 different Proteocephalus species in perch fry. Proteocephalus percae is a typical cestode parasite of perch, while $P$. longicollis (synonyms: $P$ exiguuus, $P$. neglectus) is more usually associated with salmoniform fish (reviewed by Scholz et al. 2007). Amazingly, however, our genetic analyses of a subset of cestodes from perch of the pelagic samples yielded only 1 specimen of $P$. percae. The remainder were all $P$. longicollis. We hypothesize that this prevalence of $P$. longicollis is caused by the consumption of infected plankton in the pelagial, which is the major habitat of the parasite's final host, Coregonus wartmanni (Reckel et al. 1999). Older perch, which are the definitive hosts of $P$. percae, are littoraly oriented (Wang and Eckmann, 1994) and thus a majority of P. percaeinfected copepods may be found in littoral zooplankton. However, prevalence and also intensity of Proteocephalus in perch fry decreased after 7 weeks p.h. Possible explanations for this finding include: prevalence and intensity of both Proteocephalus species rise and peak until infected zooplankton are no longer available and/or perch switch to other prey items, followed by a decrease due to (i) successive elimination of $P$. longicollis by the host's maturing immune system, (ii) deficient establishment of most parasite specimens as has been shown for a number of Proteocephalus species (reviewed in Scholz, 1999), or 
(iii) intra- and interspecific competition between young worms in the host intestine whereby $P$. percae outcompetes $P$. longicollis. These 3 hypotheses are not mutually exclusive; however, the result is the complete loss of $P$. longicollis during the later stages of perch development. The last 2 explanations could similarly lead to the observed decrease in Eubothrium crassum in perch fry. The decrease in Triaenophorus nodulosus procercoids, however, is most likely the result of a decline in infected zooplankton in spring (Lahnsteiner et al. 2009) and the additional migration of procercoids to the host's liver and subsequent development into plerocercoids.

\section{Identification of parasite species}

In total, 17 parasite species were identified in this study, including 13 found in perch fry and four additional ones found in other fish or intermediate hosts sampled in Lake Constance. Referring to perch fry, only 9 of the 13 species could be identified unambiguously by morphological characteristics alone. But an approach using a combination of informative gene sequences, gained either from unambiguously identified adult parasites sampled from older fish (cestodes) or using previously published sequences in GenBank (trematodes), allowed the successful species determination of all remaining parasites except Tylodelphys. Without additional genetic information, we certainly would have failed in distinguishing both Proteocephalus species because no morphological difference was apparent in their procercoids. Similarly, the metacercariae of trematode eye flukes of several fish hosts could not have been identified based on morphology alone (Moszczynska et al. 2009; Locke et al. 2010a,b). Here, it was the comparison of our sequences to those published in GenBank that allowed identification to the species level. However, reference sequences from macroparasites of aquatic hosts are still scarce in the databases. For trematodes, the mitochondrial CO1 sequences seem to be more useful for species determination than the rDNA sequences, because of their high inter- and lower intraspecific variability, and they have proved useful in the detection of cryptic species in North American Diplostomoidea (Moszczynska et al. 2009; Locke et al. 2010a). The high variability between $\mathrm{CO} 1$ sequences found in this study, and the unambiguous clustering supported by high bootstrap values has helped delineate different species. Unfortunately few CO1 sequences from European species are yet available for comparative analysis, and there is a need for more elaborate sampling to be carried out in the future.

In conclusion, this study showed that the genetic connection of different parasite life-cycle stages within one ecosystem provides a powerful tool for the correct identification of parasite species. It may also open the door to a new means of studying parasite transmission within ecosystems. Genetic surveys could provide independent confirmation of 'classical' life-cycle studies, such as experimental infection of various hosts. These and many further ecological, evolutionary and conservation scenarios can be imagined, in which accompanying genetic surveys provide new insights into parasite transmission pathways, parasite-host co-evolution or the spread of invasive parasite species.

\section{ACKNOWLEDGEMENTS}

The author wants to thank the following people for their help in data collection: Michael Donner, Dominik Geray and Daniela Harrer caught and analysed perch fry. Simon Weigl helped with parasite sampling from adult fish hosts and copepods and Martina Knauer sampled cercariae from snails during her diploma thesis. Julia Behr, Simon Weigl and Martina Knauer assisted with the molecular analysis. I am grateful to Reiner Eckmann, Martin Kalbe and Irene Samonte-Padilla for critical comments on the manuscript and to Amy-Jane Beer for proof reading. Additionally, the author wants to thank an anonymous referee whose comments greatly improved the manuscript.

\section{FINANCIAL SUPPORT}

This research was financially supported by the 'Stiftung für Umwelt und Wohnen' of the University of Konstanz.

\section{REFERENCES}

Andersen, K. (1978). The helminths in the gut of perch (Perca fluviatilis L.) in a small oligotrophic lake in southern Norway. Zeitschrift für Parasitenkunde 56, 17-27.

Andrews, C. (1979). Host specificity of the parasite fauna of perch Perca fluviatilis $\mathrm{L}$. from the British Isles, with special reference to a study at Llyn Tegid (Wales). Fournal of Fish Biology 15, 195-209.

Balbuena, J. A., Karlsbakk, E., Kvenseth, A. M., Saksvik, M. and Nylund, A. (2000). Growth and emigration of third-stage larvae of Hysterothylacium aduncum (nematoda: anisakidae) in larval herring Culpea harengus. Fournal of Parasitology 86, 1271-1275.

Balling, T.E. and Pfeiffer, W. (1997a). Frequency distribution of fish parasites in the perch Perca fluviatilis L. from Lake Constance. Parasitology Research 83, 370-373.

Balling, T. E. and Pfeiffer, W. (1997b). The parasitism of fish from Lake Constance: A comparison of present and earlier data. Parasitology Research 83, 793-796.

Balling, T. E. and Pfeiffer, W. (1997c). Seasonal differences in infestation of the perch Perca fluviatilis L. from Lake Constance with digenean trematodes. Parasitology Research 83, 789-792.

Balling, T. E. and Pfeiffer, W. (1997d). Location-dependent infection of fish parasites in Lake Constance. Fournal of Fish Biology 51, 1025-1032.

Bertrand, M., Marcogliese, D. J. and Magnan, P. (2008). Trophic polymorphism in brook charr revealed by diet, parasites and morphometrics. Fournal of Fish Biology 72, 555-572.

Bykhovskaya-Pavlovskaya, I., Gusev, A., Dubinina, M., Izyumova, N., Smirnova, T., Sokolovskaya, I., Shtein, G., Shul' man, S. and Epshtein, V. (1964). Key to Parasites of Freshwater Fish of the U.S.S.R. Akademiya Nauk SSSR.

Campana, S. E. (1992). Measurement and interpretation of the microstructure of fish otoliths. In Otolith Microstructure, Examination and Analysis (ed. Stevenson, K. D. and Campana, S. E.). Canadian Special Publication of Fisheries and Aquatic Sciences. 117, pp. 59-71.

Carney, J. P., and Dick, T. A. (1999). Enteric helminths of perch (Perca fluviatilis L.) and yellow perch (Perca flavescens Mitchill): stochastic or predictable assemblages? Yournal of Parasitology 85, 785-795.

Clarke, K. R. (1993). Non-parametric multivariate analyses of changes in community structure. Australian Fournal of Ecology 18, 117-143. 
Coles, T. (1981). The distribution of perch, Perca fluviatilis L. throughout their first year of life in Llyn Tegid, North Wales. Archiv für Fischereiwissenschaft 15, 193-204.

Criscione, C. D. and Blouin, M.S. (2004). Life cycles shape parasite evolution: comparative population genetics of salmon trematodes. Evolution 58, 198-202.

Eckmann, R. and Imbrock, F. (1996). Distribution and diel vertical migration of Eurasian perch (Perca fluviatilis L.) during winter. Annales Zoologici Fennici 33, 679-686.

Faltýnková, A. (2005). Laval trematodes (Digenea) in molluscs from small water bodies near Ceske Budejovice, Czech Republic. Acta Parasitologica 50, 49-55.

Faltýnková, A., Karvonen, A., Jyrkkä, M. and Valtonen, E. T. (2009) Being successful in the world of narrow opportunities: transmission patterns of the trematode Ichthyocotylurus pileatus. Parasitology 136, 1375-1382.

Galazzo, D. E., Dayanandan, S., Marcogliese, D. J. and McLaughlin, J.D. (2002). Molecular systematics of some North American species of Diplostomum (Digenea) based on rDNA-sequence data and comparisons with European congeners. Canadian Fournal of Zoology 80, 2207-2217.

Grutter, A.S., Cribb, T.H., McCallum, H., Pickering, J. L. and McCormick, M. I. (2009). Effects of parasites on larval and juvenile stages of the coral reef fish Pomacentrus moluccensis. Coral Reefs 29, 31-40.

Hall, T. A. (1999). BioEdit: a user-friendly biological sequence alignment editor and analysis program for Windows 95/98/NT. Nucleic Acids Symposium 41, 95-98.

Hanzelová, V., Scholz, T., Gerdeaux, D. and Kuchta, R. (2002). A comparative study of Eubothrium salvelini and E. crassum (Cestoda: Pseudophyllidea) parasites of arctic charr and brown trout in Alpine lakes. Environmental Biology of Fishes 64, 245-256.

Imbrock, F., Appenzeller, A. and Eckmann, R. (1996). Diel and seasonal distribution of perch in Lake Constance: a hydroacoustic study and in situ observations. Fournal of Fish Biology 49, 1-13.

Johnson, M. W., Nelson, P. A. and Dick, T. A. (2004). Structuring mechanisms of yellow perch (Perca flavescens) parasite communities: host age, diet, and local factors. Canadian fournal of Zoology 82, 1291-1301.

Johnson, P. T. J., Stanton, D. E., Preu, E. R., Forshay, K. J. and Carpenter, S. R. (2006). Dining on disease: How interactions between infection and Environment affect predation risk. Ecology 87, 1973-1980.

Kelly, D. W., Thomas, H., Thieltges, D. W., Poulin, R. and Tompkins, D. M. (2010). Trematode infection causes malformations and population effects in a declining New Zealand fish. Fournal of Animal Ecology 79, 445-452.

Kennedy, C. R. (1978). The biology, specificity and habitat of the species of Eubothrium (Cestoda: Pseudophyllidea), with reference to their use as biological tags: a review. Fournal of Fish Biology 12, 393-410.

Kimura, M. (1980). A simple method for estimating evolutionary rates of base substitutions through comparative studies of nucleotide sequences. Fournal of Molecular Evolution 16, 111-120.

King, S. D. and Cone, D. K. (2009). Infections of Dactylogyrus pectenatus (Monogenea: Dactylogyridae) on Larvae of Pimephales promelas (Teleostei: Cyprinidae) in Scott Lake, Ontario, Canada. Comparative Parasitology 76, 110-112.

Kruskal, J. B. (1964). Nonmetric multidimensional scaling: A numerical method. Psychometrika 29, 115-129.

Kuchta, R., Cech, M., Scholz, T., Soldanova, M., Levron, C. and Skorikova, B. (2009). Endoparasites of European perch Perca fluviatilis fry: role of spatial segregation. Diseases of Aquatic Organisms 86, 87-91.

Kuperman, B. I. (1981). Tapeworms of the genus Triaenophorus, Parasites of Fishes. Amerind Publishing, New York, USA.

Lahnsteiner, F., Kletzl, M. and Weismann, T. (2009). The risk of parasite transfer to juvenile fishes by live copepod food with the example Triaenophorus crassus and Triaenophorus nodulosus. Aquaculture 295, 120125.

Locke, S. A., Daniel McLaughlin, J. and Marcogliese, D. J. (2010a). DNA barcodes show cryptic diversity and a potential physiological basis for host specificity among Diplostomoidea (Platyhelminthes: Digenea) parasitizing freshwater fishes in the St. Lawrence River, Canada. Molecular Ecology 19, 2813-2827.

Locke, S. A., McLaughlin, J.D., Dayanandan, S. and Marcogliese, D. J. (2010b). Diversity and specificity in Diplostomum spp. metacercariae in freshwater fishes revealed by cytochrome c oxidase I and internal transcribed spacer sequences. International Fournal for Parasitology 40, 333-343

Marcogliese, D. J. (1995). The role of zooplankton in the transmission of helminth parasites to fish. Reviews in Fish Biology and Fisheries 5, 336-371.
McCairns, R. J. S. and Fox, M. G. (2004). Habitat and home range fidelity in a trophically dimorphic pumpkinseed sunfish (Lepomis gibbosus) population. Oecologia, 140, 271-279.

Miehls, S. M. and Dettmers, J. M. (2011). Factors Influencing Habitat Shifts of Age- 0 Yellow Perch in Southwestern Lake Michigan. Transactions of the American Fisheries Society 140, 1317-1329.

Morozinska-Gogol, J. (2008). A check-list of parasites of percid fishes (Actinopterygii: Percidae) from the estuaries of the Polish coastal zone. Helminthologia 45, 196-203.

Moszczynska, A., Locke, S. A., McLaughlin, J. D., Marcogliese, D. J. and Crease, T. J. (2009). Development of primers for the mitochondrial cytochrome c oxidase I gene in digenetic trematodes (Platyhelminthes) illustrates the challenge of barcoding parasitic helminths. Molecular Ecology Resources 9, 75 .

Nendick, L., Sackville, M., Tang, S., Brauner, C. J. and Farrell, A.P. (2011). Sea lice infection of juvenile pink salmon (Oncorhynchus gorbuscha) effects on swimming performance and postexercise ion balance. Canadian Fournal of Fisheries and Aquatic Sciences 68, 241-249.

Niewiadomska, K. and Szymanski, S. (1991). Host-induced variability of Diplostomum paracaudum (Iles, 1959) metacercariae (Digenea). Acta Parasitolgica Warszawa 36, 11-17.

Niewiadomska, K. and Kiseliene, V. (1994). Diplostomum cercariae (Digenea) in snails from Lithuania. II. Survey of species. Acta Parasitolgica Warszawa 39, 179-186.

Niewiadomska, K. and Laskowski, Z. (2002). Systematic relationships among six species of Diplostomum Nordmann, 1832 (Digenea) based on morphological and molecular data. Acta Parasitolgica Warszawa 47, 20-28. Olson, P.D., Littlewood, D. T., Bray, R. A. and Mariaux, J. (2001). Interrelationships and evolution of the tapeworms (Platyhelminthes: Cestoda). Molecular Phylogenetics and Evolution 19, 443-467.

Pracheil, B. M. and Muzzall, P. M. (2009). Chronology and development of juvenile bluegill parasite communities. Fournal of Parasitology 95, 838-845.

Pronin, N. M. (1990). Structure of the cestode population of Triaenophorus nodulosus (Pseudophyllidea, Triaenophoridae) in the ecosystem of Lake Shchuchic and the mortality of the helminth at various stages of development. Ekologija. Lietuvos Mokslu Akademija Vilnius 3, 48-55.

Reckel, F., Melzer, R. R. and Smola, U. (1999). Ultrastructure of the retina of two subspecies of Coregonus lavaretus (Teleostei) from Lake Constance (Germany). Acta Zoolgica 80, 153-162.

Rosenthal, H. (1967). Parasites in larvae of the herring (Clupea harengus L.) fed with wild plankton. Marine Biology 1, 10-15

Saitou, N. and Nei, M. (1987). The neighbor-joining method: a new method for reconstructing phylogenetic trees. Molecular Biology and Evolution 4, 406-425.

Schäperclaus, W. (1979). Fischkrankheiten. Vol 4. Akademie-Verlag, Berlin, Germany.

Scholz, T., Drabek, R. and Hanzelova, V. (1998). Scolex morphology of Proteocephalus tapeworms (Cestoda: Proteocephalidae), parasites of freshwater fish in the Palaearctic Region. Folia Parasitologica Praha 45, $27-43$.

Scholz, T. (1999). Life cycle of species of Proteocephalus, parasites of fishes in the Palearctic Region: a review. Fournal of Helmithology 73, 1-19.

Scholz, T., Hanzelova, V., Skerikova, A., Shimazu, T. and Rolbiecki, L. (2007). An annotated list of species of the Proteocephalus Weinland, 1858 aggregate sensu de Chambrier et al. (2004) (Cestoda: Proteocephalidea), parasites of fishes in the Palaearctic Region, their phylogenetic relationships and a key to their identification. Systematic Parasitology 67, 139-156.

Secombes, C. J. and Chappell, L. H. (1996). Fish immune responses to experimental and natural infection with helminth parasites. Annual Review of Fish Diseases 6, 167-177.

Skovgaard, A., Bahlool, Q.Z. M., Munk, P., Berge, T. and Buchmann, K. (2009a). Infection of North Sea cod, Gadus morhua L., larvae with the parasitic nematode Hysterothylacium aduncum Rudolphi. Fournal of Plankton Research 33, 1311-1316.

Skovgaard, A., Meneses, I. and Angélico, M. M. (2009b). Identifying the lethal fish egg parasite Ichthyodinium chabelardi as a member of Marine Alveolate Group I. Environmental Microbiology 11, 2030-2041.

Sonnenberg, R., Nolte, A. W. and Tautz, D. (2007). An evaluation of LSU rDNA D1-D2 sequences for their use in species identification. Frontiers in Zoology 4, 6.

Tamura, K., Peterson, D., Peterson, N., Stecher, G., Nei, M. and Kumar, S. (2011). MEGA5: molecular evolutionary genetics analysis using maximum likelihood, evolutionary distance, and maximum parsimony methods. Molecular Biology and Evolution 28, 2731-2739.

Valtonen, E. T., Holmes, J. C., Aronen, J. and Rautalahti, I. (2003). Parasite communities as indicators of recovery from pollution: parasites of 
roach (Rutilus rutilus) and perch (Perca fuviatilis) in central Finland. Parasitology 126 (Suppl), S43-S52.

Vojtek, J. (1989). The present situation of the research into the stage of development of trematodes in Czechoslovakia. Scripta Facultatis Scientiarum Naturalium Universitatis Prukynianae Brunensis. Brno 19 339-352.

Wang, N. and Eckmann, R. (1994). Distribution of perch (Perca fluviatilis L.) during their first year of life in Lake Constance. Hydrobiologia 277, 135143

Wang, N. and Appenzeller, A. (1998). Abundance, depth distribution, diet composition and growth of perch (Perca fluviatilis) and burbot (Lota lota) larvae and juveniles in the pelagic zone of Lake Constance. Ecology of Freshwater Fish 7, 176-183.

Weber, M. J., Dettmers, J. M. and Wahl, D. H. (2011). Growth and survival of age-0 yellow perch across habitats in southwestern Lake
Michigan: early life history in a large freshwater environment. Transactions of the American Fisheries Society 140, 1172.

Wootten, R. (1974). Studies on the life history and development of Proteocephalus percae (Müller) (Cestoda: Proteocephalidea). Fournal of Helmithology 48, 269-281.

Wootton, J. R. (1998). Ecology of Teleost Fishes, 2nd Edn. Chapman and Hall, New York, USA

Zehnder, M. P. and Mariaux, J. (1999). Molecular systematic analysis of the order Proteocephalidea (Eucestoda) based on mitochondrial and nuclear rDNA sequences. International fournal for Parasitology 29. 1841-1852.

Zelmer, D. A. and Arai, H. P. (2004). Development of nestedness: host biology as a community process in parasite infracommunities of yellow perch (Perca flavescens (Mitchill)) from Garner Lake, Alberta. Fournal of Parasitology 90, 435-436. 